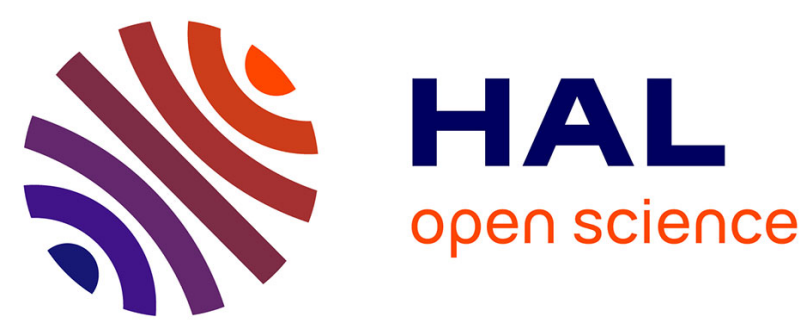

\title{
Antibacterial Activity of Wild Mushrooms Antibacterial Activity of Wild Mushrooms from France
}

\author{
Sylvie Morel, Manon Vitou, Agnès Masnou, Estelle Jumas-Bilak, Sylvie
}

Rapior, Patricia Licznar-Fajardo

\section{- To cite this version:}

Sylvie Morel, Manon Vitou, Agnès Masnou, Estelle Jumas-Bilak, Sylvie Rapior, et al.. Antibacterial Activity of Wild Mushrooms Antibacterial Activity of Wild Mushrooms from France. International Journal of Medicinal Mushrooms, 2021, 23, 10.1615/IntJMedMushrooms.2020037443 hal-03091426

\section{HAL Id: hal-03091426 \\ https://hal.umontpellier.fr/hal-03091426}

Submitted on 31 Dec 2020

HAL is a multi-disciplinary open access archive for the deposit and dissemination of scientific research documents, whether they are published or not. The documents may come from teaching and research institutions in France or abroad, or from public or private research centers.
L'archive ouverte pluridisciplinaire HAL, est destinée au dépôt et à la diffusion de documents scientifiques de niveau recherche, publiés ou non, émanant des établissements d'enseignement et de recherche français ou étrangers, des laboratoires publics ou privés. 
Short title: Antibacterial Activity of Wild Mushrooms

\section{Antibacterial Activity of Wild Mushrooms from France}

Sylvie Morel, ${ }^{\mathrm{a},{ }^{*}}$ Manon Vitou, ${ }^{\mathrm{a}}$ Agnès Masnou, ${ }^{\mathrm{b}}$ Estelle Jumas-Bilak, ${ }^{\mathrm{c}}$ Sylvie Rapior, ${ }^{\mathrm{a}}$ \& Patricia Licznar-Fajardo $^{c}$

${ }^{a}$ Laboratoire de Botanique, Phytochimie et Mycologie, UFR Sciences pharmaceutiques et biologiques, CEFE UMR 5175 CNRS - Université de Montpellier - Université Paul-Valéry Montpellier - EPHE - IRD, Montpellier, France; ' $H S M$ UMR5569 Université de Montpellier, CNRS, IRD, Montpellier, France; 'HSM UMR5569 Université de Montpellier, CNRS, IRD, Montpellier, France; Département d'Hygiène Hospitalière, CHU de Montpellier, Montpellier, France

*Address all correspondence to: Sylvie Morel, Laboratoire de Botanique, Phytochimie et Mycologie, Faculté de Pharmacie, CEFE UMR 5175 CNRS - Université de Montpellier Université Paul-Valéry Montpellier - EPHE - IRD, 15 Avenue Charles Flahault, F-34093 Montpellier Cedex 5, France, E-mail : sylvie.morel@umontpellier.fr

ABSTRACT: We selected seven wild Basidiomycota and Ascomycota mushrooms to evaluate their antibacterial activity: Cyclocybe aegerita, Cortinarius traganus, Gyroporus castaneus, Neoboletus luridiformis, Rubroboletus lupinus, Gyromitra esculenta, and Helvella crispa. Four mushrooms, three of which have never been tested, display antibacterial potential with MIC $\leq 125$ $\mu \mathrm{g} / \mathrm{mL}$ against at least one Gram-positive bacterial strain. The cyclohexanic extract of $G$. esculenta possesses the strongest antibacterial activity with MIC $=31 \mu \mathrm{g} / \mathrm{mL}$ against two strains of Staphylococcus aureus.

KEY WORDS: Basidiomycota, Ascomycota, antibacterial activity, medicinal mushrooms ABBREVIATIONS: CFU, colony-forming unit; DMSO, dimethyl sulfoxide; MBC, minimal 
bactericidal concentration; MIC, minimal inhibition concentration; MRSA, methicillin-resistant Staphylococcus aureus; MSSA, methicillin-sensitive Staphylococcus aureus.

\section{INTRODUCTION}

From 140000 estimated mushroom species worldwide distributed, only 22000 are described in literature data. ${ }^{1}$ Although there is an ongoing research to find antibacterials from mushrooms, with screening studies involving more than a hundred species or isolates, ${ }^{2-7}$ there is an important number of species not yet investigated for biological activities and/or chemical composition. For example, Hassan et al. ${ }^{8}$ estimated that 100000 species of fungi and mushrooms are never be examined for antibiotic potential. Antibacterial evaluation of mushrooms represents of promising area of research. Mushrooms $\beta$-glucans are well-studied in particular for immunomodulatory effects. $^{9-11}$ Next to these high-weight molecules, mushrooms represented an underestimated source of low-weight molecules as terpenes, steroids, phenolics, and nitrogen compounds. ${ }^{12,13}$ This makes mushrooms as a great source of new bioactive compounds. We specifically focused our research on the fruiting body of mushrooms. Indeed, sporocarp is a crucial element for the macrofungi because it leads to formation of billions spores and contribute to their dispersal, so it must be preservative against abiotic factors (UV, dryness, humidity..) and biotic factors as pathogens during its development. ${ }^{14}$ Indeed mushroom produce a large variety of compounds to survive in their environment in particular to defend itself against various microorganisms in the

soil. ${ }^{15}$ In addition, because they appear only few days or weeks for reproduction and dispersal ${ }^{16}$ we expected that sporocarps of wild mushrooms synthesized a very broad spectrum of defense compounds, such as antibacterial compounds.

Antibacterial clinical development pipeline has been edited by WHO in 2019, in particular it highlights the absence of new, suitable compounds to serve as leads for drug 
discovery. ${ }^{17}$ Indeed, antibiotic discovery had a golden age in the 1950s and 1960s; since, the number of antibiotics approved has fallen down drastically. ${ }^{17,18}$ Added to the emergence of antibiotic resistances, there is an urgent need to discover new antibiotics. Pleuromutilins are natural products firstly isolated from Clitopilus passeckerianus (Pilát) Singer (synonym: Pleurotus passeckerianus Pilát) and Pleurotus mutilus (Fr.) Gillet. ${ }^{19}$ They are also present in some other Clitopilus species. ${ }^{20}$ They inhibit bacterial protein synthesis by binding at two sites to the peptidyltransferase center of the ribosomal 50S subunit of the bacterial ribosome. ${ }^{17}$ From these isolated pleuromutilins lead components have been developed the local antibiotic retapamulin to treat impetigo ${ }^{21}$ and the systemic lefamulin for the treatment of communityacquired bacterial pneumonia since $2019 .{ }^{22}$

In this context, we evaluated the antibacterial activity of 28 extracts from seven species of Basidiomycota and Ascomycota mushrooms against Gram- positive and Gram-negative strains in order to selected species for bio-guided purification.

\section{MATERIALS AND METHODS}

\section{A. Mushroom Material}

Mushrooms were collected from their natural habitats in the Montpellier area in 2012-2013 and 2014. The sporocarps were taxonomically identified by qualified mycologists using monographs and reference keys. ${ }^{23,24}$ Information about the wild species collected is provided in Table 1. Fresh mushrooms were cleaned, sliced, frozen, and kept at $-20^{\circ} \mathrm{C}$ until they were freeze-dried. Voucher specimens were deposited as n CA140920, CT140926, GC150914, NL140926, RL121023, GE131006, HC141117 at the Laboratoire de Botanique, Phytochimie et Mycologie, Faculté de Pharmacie, Montpellier (France). Lyophilized mushrooms were ground before extraction. 


\section{B. Materials and Reagents}

Cyclohexane (99.8\%), chloroform (99\%), and dimethyl sulfoxide (DMSO; 99.9\%) were purchased from Sigma-Aldrich (Steinheim, Germany). Ethanol (99.9\%) and Mueller-Hinton medium with and without agar were purchased from BD-Difco (Franklin Lakes, NJ).

\section{Mushroom Extracts Preparation}

Sequential extraction was performed as previously described ${ }^{25}$ using solvents with increasing polarity (cyclohexane, chloroform, ethanol and water) to extract both non-polar and polar compounds (10 mL solvent/g freeze-dried mushroom). The extraction was conducted under sonication (90 minutes) and temperature was maintained below $35^{\circ} \mathrm{C}$. After filtration, the solvents were removed to dryness using a vacuum rotary evaporator (water bath maintained at $35^{\circ} \mathrm{C}$ ) and yielded four extracts per mushroom species. Powdered extracts were kept at $-20^{\circ} \mathrm{C}$

until testing. Extraction yields were calculated as (Mass of dried extract in g/Mass of freezedried mushroom in g) $\times 100$, and were expressed as a percentage. Total yield was defined as (Sum of masses of dried extracts/ Mass of freeze-dried mushroom in $\mathrm{g}$ ) $\times 100$, and was expressed as a percentage (Table 1).

\section{Microorganism Strains}

Anti-microbial activities were tested against Pseudomonas aeruginosa ATCC9027 strain and Escherichia coli ATCC8739 strain as Gram-negative; Staphylococcus aureus ATCC6538 (MSSA: methicillin-sensitive S. aureus and B5284 MRSA: methicillin-resistant S. aureus) strains and Bacillus subtilis ATCC6633 strain as Gram-positive. The bacteria were grown on Mueller-Hinton (MH, Difco) medium.

\section{E. Antibacterial Assay by Dilution Method}

\section{MIC (Minimal Inhibition Concentration)}


Dried mushroom extracts were first diluted in DMSO (20 mg/mL). Then, dilutions were carried out in distilled water to obtain concentrations ranging from $500 \mu \mathrm{g} / \mathrm{mL}$ to $7.8 \mu \mathrm{g} / \mathrm{mL}$ per well. The highest dilution contains $2.5 \%$ of DMSO. At this concentration DMSO has no effect on bacterial grown (effect on bacterial growth at 10\% DMSO). $100 \mu \mathrm{L}$ of each strain inoculum $\left(10^{6}\right.$ $\mathrm{CFU} / \mathrm{mL}$ ) and $100 \mu \mathrm{L}$ of diluted extracts were added in 96-well plates in duplicate. Controls without extracts (positive control of bacterial growth) and extracts without bacterial strains (sterility control) were prepared. After $24 \mathrm{~h}$ of incubation at $37^{\circ} \mathrm{C}$ and controls validation, MIC was determined as the concentration of extract that inhibits visible bacterial growth. The results are based on three independent experiments.

\section{MBC (Minimal Bactericidal Concentration)}

To determine MBC, $1 \mu \mathrm{L}$ of each well from the 96-well plates was plated to a Petri dish containing Mueller-Hinton agar using a Mic-2000 inoculator (Dynatech). After $24 \mathrm{~h}$ incubation, MBC was determined as the lowest concentration that prevents the growth of more than $99.9 \%$ of the initial inoculum. The results are based on three independent experiments. The MBC/MIC ratio gives an indication of the effects of the extract. An extract with $\mathrm{MBC} / \mathrm{MIC} \geq 16$ is considered as bacteriostatic, whereas an extract with $\mathrm{MBC} / \mathrm{MIC} \leq 4$ is considered as bactericidal. ${ }^{26}$

\section{RESULTS AND DISCUSSION}

Non-polar and polar extracts from seven wild mushrooms (Table 1) were evaluated for their antibacterial activity against three Gram-positive strains (Table 2) and two Gram-negative strains. Mushrooms were sequentially extracted with increasing polarity solvents: cyclohexane, chloroform, ethanol and water. As previously report, ${ }^{25}$ the highest yields of extraction were obtained with water (15.43\% to $34.79 \%)$ suggesting an important quantity of polar compounds 
such as phenolics and carbohydrates. Ethanol gives variable yields of extraction depending of the species (between $2.1 \%$ for C. aegerita and $12.3 \%$ for $R$. lupinus). Large difference was also observed previously in a comparative study of 25 mushrooms from different genus sequentially extracted with $\mathrm{C}_{6} \mathrm{H}_{12}$, dichloromethane and methanol. ${ }^{27}$ In this study, yields of extraction with methanol vary from $9.90 \%$ to $41.29 \% .{ }^{27}$ In some Boletales important difference was also observed (yields with ethanol: 6.53-17.98\%). ${ }^{25}$ The yields of extraction were comprise between $1.06 \%$ and $3.46 \%$ with cyclohexane and between $0.89 \%$ and $2.71 \%$ with chloroform in accordance with those previously reported with the same method (1.31-4.03\% for $\mathrm{C}_{6} \mathrm{H}_{12}$ and 1.05-3.55 for $\left.\mathrm{CHCl}_{3}\right)^{25}$ and with a closest method $\left(0.61-4.39 \%\right.$ for $\mathrm{C}_{6} \mathrm{H}_{12}$ and $0.52-3.52 \%$ for $\left.\mathrm{CH}_{2} \mathrm{Cl}_{2}\right)^{27}$

Large screenings of Basidiomycetes can be performed using the disk diffusion method. ${ }^{2-}$ ${ }^{4,28}$ However, this method cannot distinguish bactericidal and bacteriostatic effects. ${ }^{29}$ Moreover, some compounds cannot diffuse through. ${ }^{29}$ No MIC values can be easily determined with the disk method. Disk diffusion method is not appropriate for lipophilic extract that do not easily diffuse into agar. $^{30}$ Thin-layer chromatography (TLC)-bioautography can also be used to determine antimicrobial activity of crude extract. ${ }^{29,31}$ It is not a quantitative method (no MIC values), but has the advantage to determine whether one or several compounds from a crude extract are active. Moreover, chromatographic conditions must be optimized before the antibacterial assay.

Dilution methods take the advantage to be conducted on both non-polar and polar extracts and give MIC and MBC values then selection of active extract is easy. However, this method is longer to performed (dilutions in 96-well plates) than diffusion methods. Depending on the studies, ${ }^{32-40}$ the MIC value to classify the extracts as active or inactive is different. MIC values 
for mushrooms active extracts range from $0.25 \mu \mathrm{g} / \mathrm{mL}$ to $100 \mathrm{mg} / \mathrm{mL}$ according to the authors. ${ }^{32-}$ 40 The inoculum is the most relevant elements to consider for comparison of antibacterial activity (from $10^{4}$ to $10^{7}$ in the publications on Basidiomycetes previously cited). Indeed, a low inoculum (e.g., $10^{2} \mathrm{CFU} / \mathrm{ml}$ ) will create false-positive data, whereas a high inoculum size (e.g., $10^{7}$ CFU/ml) increase false-negative data. ${ }^{32}$ Consequently, according to literature, ${ }^{32}$ an inoculum of $10^{5} \mathrm{CFU} / \mathrm{mL}$ in the final wells seems to be adequate to investigate mushroom extracts for antibacterial properties. Taking into account these elements, we decided to separate the mushroom extracts in three categories: active extracts with $\mathrm{MIC}<125 \mu \mathrm{g} / \mathrm{mL}$, moderate active extracts with MIC between $125 \mu \mathrm{g} / \mathrm{mL}$ and $500 \mu \mathrm{g} / \mathrm{mL}$ and inactive extracts with MIC > 500 $\mu \mathrm{g} / \mathrm{mL}$.

All the tested mushroom extracts were inactive on both Gram-negative strains $P$. aeruginosa and E. coli. These results are in agreement with literature. ${ }^{2,32,41}$ It has been wellestablished that Gram-positive bacteria are much more sensitive than Gram-negative bacteria. ${ }^{32}$ Gram-positive strains possess a thick peptidoglycan layer above the lipidic cytoplasmic membrane, whereas the Gram-negative bacteria are bounded by an outer lipidic cell membrane, a thin peptidoglycan layer and the cytoplasmic membrane. We can note that all the ethanolic and aqueous extracts are inactive whatever the mushroom species and the bacterial strain (Table 2).

Among the seven species evaluated, four mushrooms, G. castaneus, $N$. luridiformis, $R$. lupinus, and G. esculenta, display notable activities against Gram-positive strains: S. aureus and/or B. subtilis (Table 2).

\section{A. Gyroporus castaneus}

The antibacterial activity of this mushroom had never been tested before. In a previous study, the cyclohexanic and chloroformic extracts presented a moderate antiproliferative activity 
against human colon cancer cell lines HCT116; in addition, the ethanolic extract had an antioxidant potential using the DPPH (2,2-diphenyl-1-picrylhydrazyl) assay, and the aqueous extract present a significant capacity with both Folin-Ciocalteu and ORAC (Oxygen Radical Absorbance Capacity) assays. ${ }^{25}$ As reported in Table 2, the cyclohexanic extract displays an interesting antibacterial activity against both strains of S. aureus (MRSA and MSSA). Moreover, the cyclohexanic extract has a bactericidal activity, with ratio $\mathrm{MBC} / \mathrm{MIC}=4$ calculated for MRSA whereas the ratio is beyond 4 with MSSA. The chloroformic extract shows an activity against only MRSA strain. Further purifications are necessary to identify the antibacterial compounds, as they are present in non-polar extracts, they are probably sterols, fatty acids, or terpenoids. From this mushroom species only ergosterol derivatives and phenolic acids have been described. $^{42,43}$

\section{B. Neoboletus luridiformis}

Although a dichloromethane extract of $N$. luridiformis has been previously tested on TLCbioautography on E. coli and B. subtilis, ${ }^{31}$ this is the first investigation for a broad spectrum of antimicrobial activities of this species using a dilution method. Table 2 shows that the cyclohexanic extract is more active on MSSA strain than MRSA. The same result is observed for the chloroformic extract (moderate activity against MSSA and no activity against MRSA). This implies that the compound(s) responsible for the activity on S. aureus is/are present in large quantities in cyclohexanic extract and less in chloroformic extract. It should be noted that MBC values are $>500 \mu \mathrm{g} / \mathrm{mL}$, suggesting that the active compounds are bacteriostatic agents. No $N$. luridiformis extracts are active against $E$. coli and $B$. subtilis unlike a dichloromethane extract tested on TLC-autobiography by Keller et al. ${ }^{31}$ Few studies concern the composition of this edible mushroom. Only the content of macronutrients, vitamins (tocopherols and ascorbic acid) 
and total phenolics is reported. ${ }^{44}$ Moreover, a polyphenol oxidase has been purified from $N$. luridiformis. $^{45}$

\section{Rrubroboletus lupinus}

We previously reported the antioxidant capacity and anti-proliferative activity on human colon cancer cells (HCT116) of R. lupinus. ${ }^{25}$ The cyclohexanic extract of $R$. lupinus possesses activity against MRSA with MIC value of $125 \mu \mathrm{g} / \mathrm{mL}$ (Table 2), whereas the same extract displays a moderate activity against MSSA and B. subtilis strains (MIC=250 $\mu \mathrm{g} / \mathrm{mL}$ ). These results are partially in agreement with literature. Indeed, a methanolic extract of $R$. lupinus have been previously evaluated for antibacterial activity. ${ }^{39}$ The MIC values were determined to be 6.25 $\mathrm{mg} / \mathrm{mL}$ against B. subtilis and Sarcina lutea (Micrococcus luteus), $25 \mathrm{mg} / \mathrm{mL}$ against Bacillus pumilus and $P$. aeruginosa, $50 \mathrm{mg} / \mathrm{mL}$ against $S$. aureus (MSSA) strain. ${ }^{39}$ Taken together, these results indicate that $R$. lupinus has antimicrobial compounds. The MRSA strain is more sensible than MSSA strains. A moderate activity against B. subtilis is confirmed by our results. The difference between our values (Table 2) and those of Nikolovska-Nedelkoska et al. ${ }^{39}$ can be explained by variations in inoculum, bacterial strains, and method applied, or intra-species variations and geographical considerations. Indeed variation in antibacterial activity was observed for different isolates of the same species. ${ }^{8}$

\section{Gyromitra esculenta}

Our results show that the cyclohexanic extracts possess a significant antimicrobial activity against MRSA and MSSA, with MIC values of $31 \mu \mathrm{g} / \mathrm{mL}$. The MBC values were $125 \mu \mathrm{g} / \mathrm{mL}$, suggesting a relevant bactericidal effect. A moderate activity was observed against $B$. subtilis (MIC=125 $\mu \mathrm{g} / \mathrm{mL}$ ). The chloroformic extract displays a significant activity against MRSA and MSSA with MIC=125 $\mu \mathrm{g} / \mathrm{mL}$, probably explained by the same antimicrobial compounds in 
lesser quantities than in the cyclohexanic extract. Extracts of G. esculenta have been evaluated on foodborne bacterial strains. ${ }^{46}$ Only a methanolic extract present a moderate activity on Clostridium perfringens, whereas all the extracts (obtained with water, methanol, hexane and ethyl acetate) are inactive against S. aureus. ${ }^{46}$ This species is poor documented about beneficial biological activities. Indeed, the published studies focused on the toxins (gyromitrin derivatives) and the mechanism of their toxicity. Gyromitrin and derivatives are hydrazide compounds. Hydrazide derivatives have been also isolated from the genus Streptomyces. ${ }^{47}$ For example, negamycin has exhibited to exert a strong inhibition against $P$. aeruginosa, E. coli and $S$. aureus. ${ }^{48}$ Nevertheless, it can be observed that hydrazide derivatives are polar compounds ${ }^{49,50}$ so they cannot be responsible for the antimicrobial activity present in the non-polar extracts of $G$. esculenta; more preferably lipophilic compounds are responsible for this promising activity. So bio guided purifications of this toxic mushroom must be performed to explain the antimicrobial effect.

\section{E. Cyclocybe aegerita}

All the extracts of edible $C$. aegerita tested in the present study are considered inactive (MIC>500 $\mu \mathrm{g} / \mathrm{mL}$ ). Conflicting results concern this species. Indeed, an hydro-methanolic extract shows no activity on 13 bacterial strains. ${ }^{51}$ A methanolic extract of $C$. aegerita had shown a moderate antimicrobial activity with $\mathrm{MIC}=0.59 \mathrm{mg} / \mathrm{mL}{ }^{40}$ Whereas an ethanolic extract of $C$. aegerita presented no activity against Helicobacter pylori, S. aureus and E. coli. ${ }^{52}$ The difference observed can be explained by extraction, antibacterial assay procedures or intra-species variations. From the genus Cyclocybe (synonym: Agrocybe), several compounds were isolated. Recently a ribotoxin named ageritin, was isolated and presents defensive and antiproliferative activities. $^{53}$ Some of them have been evaluated for antibacterial potential. Indeed, a compound 
named agrocybin, isolated from culture of Agrocybe dura exhibited activity against Gramnegative bacteria with MIC values between 0.5 and $1 \mathrm{mg} / \mathrm{mL}$ against B. subtilis, E. coli, $P$. aeruginosa and S. aureus; ${ }^{54}$ nevertheless, during this study, the structure was not elucidated. A bio guided fractionation of an active extract from culture of $C$. aegerita was realized using antifungal model; ${ }^{55}$ unfortunately, the structure of the bioactive compound was still not totally elucidated using NMR analyses. The mass spectrometry suggests a sesquiterpenic structure. ${ }^{55}$ More recently, a peptide also named agrocybin was isolated from A. aegerita and showed antifungal activity. ${ }^{56}$ Agrocybolaton, with an unusual tetracyclic ring system, isolated from a culture of Agrocybe sp., revealed a moderate antibacterial activity against B. subtilis and $M$. smegmatis. ${ }^{57}$ Several terpenoids were isolated from submerged cultures of C. aegerita but only pasteurestin C and bovistol have been evaluated on bacterial strain, but no activity were observed..$^{58}$

\section{F. Cortinarius traganus}

No activity was observed for pear-like odorous $C$. traganus whatever the extracts and the bacterial strains used in our study (Table 2). Fragner ${ }^{59}$ has isolated an antibacterial substance from C. traganus, but unfortunately, the structure has never been elucidated. Furthermore, this compound seems to be thermolabile (loss of activity after $40 \mathrm{~min}$ in autoclave). This mushroom has never been previously investigated for broad antibacterial property.

\section{G. Helvella crispa}

In the present study, we noted a weak activity of the non-polar extracts (cyclohexanic and chloroformic) against both S. aureus strains (MSSA and MRSA). Surprising H. crispa had never been evaluated for antibacterial activity before. $H$. crispa is a common and widely distributed mushroom in Europe. ${ }^{24}$ Even this mushroom is traditionally eaten after a specific cooking; it 
must be considered as inedible because it contains hydrazide derivatives such as $G$. esculenta. ${ }^{50}$ Few studies concern this species. Sterols, fatty acids, amino acids and mannitol have been isolated or detected. ${ }^{60,61}$ Water and methanolic extracts of $H$. crispa have been evaluated for antioxidant potential. ${ }^{62}$ In addition, an aqueous extract of $H$. crispa produces a mild inhibition of the prostaglandin biosynthesis. ${ }^{61}$

\section{CONCLUSIONS}

Mushrooms appear as an interesting source of antibacterial agents. Seven mushroom species were screened for their antibacterial potential. Three species have never been investigated for their antibacterial activity, i.e., G. castaneus, N. luridiformis, and H. crispa. C. traganus has previously been evaluated but data on isolated antibacterial compound is missing. C. aegerita and $R$. lupinus alcoholic extracts have been previously tested but not the non-polar extracts. In our study, sequential extractive process was performed with increasing polarity solvents: cyclohexane, chloroform, ethanol and water. Then 28 extracts were evaluated for their antibacterial activity against five strains: methicillin-sensitive $S$. aureus strain, methicillinresistant $S$. aureus strain and $B$. subtilis as Gram- positive strains as well as $P$. aeruginosa and $E$. coli as Gram-negative strains.

All the 28 extracts are inactive against Gram-negative strains. However, our results do not confirm the antibacterial activity observed previously for C. traganus and for C. aegerita. $R$. lupinus is active on MRSA and mildly active on MSSA and B. subtilis. Our differences with literature can be explained by various extractive processes, antibacterial assay procedure or by chemical intraspecific variations, geographically considerations. $H$. crispa presents a moderate activity on S. aureus strains. Interestingly, G. castaneus, N. luridiformis and G. esculenta have promising antibacterial activity with $\mathrm{MIC} \leq 125 \mu \mathrm{g} / \mathrm{mL}$ on at least one bacterial strain. Only the 
non-polar extracts (cyclohexanic and chloroformic) are active. Among the seven species tested, three boletes G. castaneus, $N$. luridiformis and $R$. lupinus possess moderate (MIC=250 $\mu \mathrm{g} / \mathrm{mL}$ ) or good activity $(\mathrm{MIC}=125 \mu \mathrm{g} / \mathrm{mL})$ against one bacterial strain. This finding suggests that common compounds in the group are involved in the activity. G. esculenta displays the best activity against $S$. aureus with $\mathrm{MIC}=31 \mu \mathrm{g} / \mathrm{mL}$. This toxic mushroom can be a promising source of antibacterials. Further bio guided purifications should be carried out to identify the promising antibacterial compounds highlighted in our study.

\section{ACKNOWLEDGMENTS}

The authors are grateful to Jacqueline Casadebaig, Luc Maury and SHHNH (Société d'Horticulture et d'Histoire Naturelle de l'Hérault) for collecting some of the mushroom samples. The authors are thankful Maria Sarri for her technical assistance during her bachelor's degree.

\section{REFERENCES}

1. Lindequist U, Timo JH, Julich WD. The pharmacological potential of mushrooms. Evid Based Complement Altern Med. 2005;2(3):285-99.

2. Suay I, Arenal F, Asensio FJ, Basilio A, Cabello MA, Diez MT, Garcia JB, Gonzalez del Val A, Gorrochategui J, Hernandez P, Pelaez F, Vicente MF. Screening of Basidiomycetes for antimicrobial activities. Antonie Van Leeuwenhoek. 2000;78:129-39.

3. Hervey AH. A survey of 500 Basidiomycetes for antibacterial activity. Bull Torrey Bot Club. 1947;74(6):476-503.

4. Rosa LH, Machado KM, Jacob CC, Capelari M, Rosa CA, Zani CL. Screening of Brazilian Basidiomycetes for antimicrobial activity. Mem Inst Oswaldo Cruz. 2003;98(7):967-74.

5. Beattie KD, Rouf R, Gander L, May TW, Ratkowsky D, Donner CD, Gill M, Grice D, 
Tiralongo E. Antibacterial metabolites from Australian macrofungi from the genus Cortinarius. Phytochemistry. 2010;71:948-55.

6. Dighe S, Agate AD. Antibacterial activity of some Indian mushrooms. Int J Med Mushrooms. 2000;2:141-50.

7. Duncan CJG, Cibula W, Ross SA. A survey of Southeast North American wild growing macromycetes (higher Basidiomycetes and Ascomycetes) sporophores for biological activity. Int J Med Mushrooms. 2003;5:171-80.

8. Hassan F, Ni S, Becker TL, Kinstedt CM, Abdul-Samad JL, Actis LA, Kennedy MA. Evaluation of the antibacterial activity of 75 mushrooms collected in the Vicinity of Oxford, Ohio (USA). Int J Med Mushrooms. 2019;21(2):131-41.

9. Wasser SP. Medicinal mushroom science: history, current status, future trends, and unsolved problems. Int J Med Mushrooms. 2010;12(1):1-16.

10. Zhu F, Du B, Bian Z, Xu B. Beta-glucans from edible and medicinal mushrooms: characteristics, physicochemical and biological activities. J Food Compos Anal. 2015;41:16573.

11. Bai J, Ren Y, Li Y, Fan M, Qian H, Wang L, Wu G, Zhang H, Qi X, Xu M, Rao Z. Physiological functionalities and mechanisms of $\beta$-glucans. Trends Food Sci Technol. 2019;88:57-66.

12. Wasser SP. Medicinal mushrooms in human clinical studies. Part I. Anticancer, oncoimmunological, and immunomodulatory activities: a review. Int J Med Mushrooms. 2017;19(4):279-317.

13. De Silva DD, Rapior S, Sudarman E, Stadler M, Xu J, Alias SA, Hyde KD. Bioactive metabolites from macrofungi: ethnopharmacology, biological activities and chemistry. Fungal 
Divers. 2013;62:1-40.

14. Schwan WR. Mushrooms: an untapped reservoir for nutraceutical antibacterial applications and antibacterial compounds. Curr Top Nutraceut Res. 2012;10(1):75+.

15. Rai M, Gaikwad S, Nagaonkar D, Alves dos Santos C. Current advances in the antimicrobial potential of species of genus Ganoderma (higher Basidiomycetes) against human pathogenic microorganisms (review). Int J Med Mushrooms. 2015;17(10):921-32.

16. Halbwachs H, Simmel J, Bassler C. Tales and mysteries of fungal fruiting: How morphological and physiological traits affect a pileate lifestyle. Fungal Biol Rev. 2016;30:36-61. 17. World Health Organization. Antibacterial agents in clinical development: an analysis of the antibacterial clinical development pipeline. 2019.

18. Ventola CL. The antibiotic resistance crisis: part 1: causes and threats. Pharm Ther. 2015;40(4):277-83.

19. Kavanagh F, Hervey AH, Robbins WJ. Antibiotic substances from Basidiomycetes. VIII. Pleurotus multilus (Fr.) Sacc. and Pleurotus passeckerianus Pilat. Proc Natl Acad Sci USA. 1951;37(9):570-4.

20. Hartley AJ, de Mattos-Shipley K, Collins CM, Kilaru S, Foster GD, Bailey AM. Investigating pleuromutilin producing Clitopilus species and related basidiomycetes. FEMS Microbiol Lett. 2009;297:24-30.

21. Gargano ML, van Griensven LJLD, Isikhuemhen OS, Venturella G, Wasser SP, Zervakis GI. Medicinal mushrooms: valuable biological resources of high exploitation potential. Plant Biosyst. 2017;151(3):548-65.

22. U.S. Food \& Drug Administration. FDA approves new antibiotic to treat communityacquired bacterial pneumonia. Httpswwwfdagovnews-Eventspress-Announc-Approv-New- 
Antibiot-Treat-Community-Acquir-Bact-Pneumonia. 2019.

23. Courtecuisse R, Duhem B. Champignons de France et d'Europe. Delachaux et Niestlé. Paris; 2013. 543p.

24. Eyssartier G, Roux P. Le guide des champignons France et Europe. Editions Belin. Paris; 2013. 1119 p.

25. Morel S, Arnould S, Vitou M, Boudard F, Guzman C, Poucheret P, Fons F, Rapior S. Antiproliferative and antioxidant activities of wild Boletales mushrooms from France. Int J Med Mushrooms. 2018;20(1):13-29.

26. Wald-Dickler N, Holtom P, Spelberg B. Busting the myth of "Static vs Cidal": a systemic literature review. Clin Infect Dis. 2018;66(9):1470-4.

27. Smolskaite L, Talou T, Venskutonis PR. Comprehensive evaluation of the antioxidant potential of coastal dune mushroom species from the southwest of France. Int $\mathrm{J}$ Med Mushrooms. 2016;18(11):1023-35.

28. Rosenberger MG, Paulert R, Cortez VG. Studies of the antimicrobial activity of mushrooms (Agaricales) from South America (review). Int J Med Mushrooms. 2018;20(11):1065-74.

29. Balouiri M, Sadiki M, Ibnsouda SK. Methods for in vitro evaluating antimicrobial activity: a review. J Pharm Anal. 2016;6:71-9.

30. Scorzoni L, Benaducci T, Fusco Almeida AM, Siqueira Silva DH, da Silva Bolzani V, Soares Mendes Gianinni MJ. The use of standard methodology for determination of antifungal activity of natural products against medical yeasts Candida sp. and Cryptococcus sp. Braz J Microbiol. 2007;38:391-7.

31. Keller C, Maillard M, Keller J, Hostettmann K. Screening of European fungi for antibacterial, antifungal, larvicidal, molluscicidal, antioxidant and free-radical scavenging 
activities and subsequent isolation of bioactive compounds. Pharm Biol. 2002;40(7):518-25.

32. Cos P, Vlietinck AJ, Berghe DV, Maes L. Anti-infective potential of natural products: How to develop a stronger in vitro 'proof-of-concept.' J Ethnopharmacol. 2006;106:290-302.

33. Gerstel J, Turner T, Ruiz G, Wise J, Stein A, Jones G, Morin T, Pinazza T, Sukhorukov E, Clark D, Steen T, Wright B, Langland J. Identification of botanicals with potential therapeutic use against methicillin-resistant Staphylococcus aureus (MRSA) infections. Phytother Res. 2018;32:2577-85.

34. Klancnik A, Megusar P, Stenisa M, Jersek B, Bucar F, Mozina SS, Kos J, Sabotic J. Aqueous extracts of wild mushrooms show antimicrobial and antiadhesion activities against bacteria and fungi. Phytother Res. 2017;31:1971-6.

35. Barros L, Calhelha RC, Vaz JA, Ferraira ICFR, Baptista P, Estevinho LM. Antimicrobial activity and bioactive compounds of Portuguese wild edible mushrooms methanolic extracts. Eur Food Res Technol. 2007;225:151-6.

36. Alves MJ, Ferreira ICFR, Martins A, Pintado M. Antimicrobial activity of wild mushroom extracts against clinical isolates resistant to different antibiotics. J Appl Microbiol. 2012;113:466-75.

37. Bach F, Ferreira Zielinski AA, Helm CV, Maciel GM, Pedro AC, Stafussa AP, Aviala S, Haminiuk CWI. Bio compounds of edible mushrooms: in vitro antioxidant and antimicrobial activities. LWT-Food Sci Technol. 2019;107:214-20.

38. Taofiq O, Heleno SA, Calhelha RC, Alves MJ, Barros L, Barreiro MF, Ferreira ICFR. Development of mushroom-based cosmeceutical formulations with anti-Inflammatory, antityrosinase, antioxidant, and antibacterial properties. Molecules. 2016;21:E1372.

39. Nikolovska-Nedelkoska D, Pancevska NA, Amedi H, Veleska D, Ivanova E, Karadelev M, 
Kungulovski D. Screening of antibacterial and antifungal activities of selected Macedonian wild mushrooms. Matica Srp J Nat Sci. 2013;124:333-40.

40. Petrovic J, Glamoclija J, Stojkoviic D, Nikolic M, Ciric A, Fernandes A, Ferreira ICFR, Sokovic M. Bioactive composition, antimicrobial activities and the influence of Agrocybe aegerita (Brig.) Sing. on certain quorum-sensing-regulated functions and biofilm formation by Pseudomonas aeruginosa. Food Funct. 2014;5:3296-303.

41. Smania, Jr A, Delle Monache F, Loguercio-Leite C, Smania EFA, Gerber AL. Antimicrobial activity of Basidiomycetes. Int J Med Mushrooms. 2001;3:87.

42. Wan H, Sun R, Wu D, Guo B. Three sterols from Gyroporus castaneus. Nat Prod Res Dev. 1999;11(6):18-21.

43. Yang D, Tang $\mathrm{X}$, Zhang $\mathrm{Y}, \mathrm{Xu}$ S. Chemical constituents of Gyroporus castaneus. Zhongcaoyao. 2000;31(5):328-30 (in Chinese).

44. Grangeia C, Heleno SA, Barros L, Martins A, Ferraira ICFR. Effects of trophism on nutritional and nutraceutical potential of wild edible mushrooms. Food Res Int. 2011;44:1029_ 35.

45. Ozel A, Colak A, Arslan O, Yildirim M. Purification and characterisation of a polyphenol oxidase from Boletus erythropus and investigation of its catalytic efficiency in selected organic solvents. Food Chem. 2010;119:1044-9.

46. Venturini ME, Rivera CS, Gonzalez C, Blanco D. Antimicrobial activity of extracts of edible wild and cultivated mushrooms against foodborne bacterial strains. J Food Prot. 2008;71(8):1701-6.

47. Le Goff G, Ouazzani J. Natural hydrazine-containing compounds: biosynthesis, isolation, biological activities and synthesis. Bioorg Med Chem. 2014;22:6529-44. 
48. Hamada M, Tadeuchi T, Kondo S, Ikeda Y, Naganawa H, Maeda K, Okami Y, Umezawa H. A new antiobiotic, negamycin. J Antibiot (Tokyo). 1970;23(3):170-1.

49. Arlukowicz-Grabowska M, Wojcicki M, Raszeja-Wyszomirska J, Szydłowska-Jakimiuk M, Piotuch B, Milkiewicz P. Acute liver injury, acute liver failure and acute on chronic liver failure: a clinical spectrum of poisoning due to Gyromitra esculenta. Ann Hepatol. 2019;18:514-6.

50. Puschner B. Chapter 67: Mushroom toxins (Veterinary Toxicology). In: Third Edition, Academic Press, Cambridge, 2018. p. 955-66.

51. Karaman M, Stahl M, Vulic J, Vesic M, Canadanovic-Brunet J. Wild-growing lignicolous mushroom species as sources of novel agents with antioxidative and antibacterial potentials. Int $\mathrm{J}$ Food Sci Nutr. 65(3):331-19.

52. Shang X, Tan Q, Liu R, Yu K, Li P, Zhao GP. In vitro anti-Helicobacter pylori effects of medicinal mushroom extracts, with special emphasis on the lion's mane mushroom, Hericium erinaceus (higher Basidiomycetes). Int J Med Mushrooms. 2013;15(2):165-74.

53. Citores L, Ragucci S, Ferreras JM, Di Maro A, Iglesias R. Ageritin, a ribotoxin from poplar mushroom (Agrocybe aegerita) with defensive and antiproliferative activities. ACS Chem Biol. 2019;14:1319-27.

54. Kavanagh F, Hervey AH, Robbins WJ. Antibiotic substances from Basidiomycetes. VI. Agrocybe dura. Proc Natl Acad Sci USA. 1950;36(2):102-6.

55. Stransky K, Semerdzieva M, Otmar M, Prochazka Z, Budesinsky M, Ubik K, Kohoutova J, Streinz L. Antifungal antibiotic from the mushroom Agrocybe aegerita (Brig.) Sing. Collect Czechoslov Chem Commun. 1992;57(3):590-603.

56. Ngai PH, Zhao Z, Ng TB. Agrocybin, an antifungal peptide from the edible mushroom Agrocybe cylindracea. Peptides. 2005;26(2):191-6. 
57. Berg A, Dorfelt H, Kiet TT, Schlegel B, Grafe U. Agrocybolacton, a new bioactive metabolite from Agrocybe sp. HKI 0259. J Antibiot (Tokyo). 2002;55(9):818-20.

58. Surup F, Hennicke F, Sella N, Stroot M, Bernecker S, Pfutze S, Stadler M, Ruhl M. New terpenoids from the fermentation broth of the edible mushroom Cyclocybe aegerita. Beilstein $\mathrm{J}$ Org Chem. 2019;15:1000-7.

59. Fragner P. A new antibacterial substance from Inoloma traganum (Inolomin). Experientia. 1949;15(4):167.

60. Lalioti M, Gonou-Zagou Z, Aligiannis N, Skaltsounis AL, Fokialaskis N. Isolation of metabolites from the wild mushrooms Helvella lacunosa and Helvella crispa. Planta Medica Congr Abstr. 2009;75(09):PJ78.

61. Capasso F, Cerri R, De Simone F, Ramundo E, Senatore F. Sterols, fatty acids and free amino acids from two Helvella species. Biochem Syst Ecol. 1982;10(4):285-7.

62. Puttaraju NG, Venkateshaiah SU, Dharmesh SM, Urs SMN, Somasundaram R. Antioxidant activity of indigenous edible mushrooms. J Agric Food Chem. 2006;54:9764-72.

TABLE 1: Information about the wild mushrooms evaluated

\begin{tabular}{|c|c|c|c|}
\hline Mushroom names and edibility/toxicity & Extracts & $\begin{array}{l}\text { Extraction } \\
\text { yield (\%) }\end{array}$ & $\begin{array}{l}\text { Total } \\
\text { yield (\%) }\end{array}$ \\
\hline \multicolumn{4}{|l|}{ Basidiomycota } \\
\hline Cyclocybe aegerita (V. Brig.) Vizzini & cyclohexane & 1.19 & \multirow[t]{4}{*}{39.65} \\
\hline Poplar mushroom, & chloroform & 1.57 & \\
\hline \multirow[t]{2}{*}{ Good edible } & ethanol & 2.10 & \\
\hline & water & 34.79 & \\
\hline Cortinarius traganus (Fr.) Fr. & cyclohexane & 1.06 & \multirow[t]{2}{*}{35.91} \\
\hline Gassy webcap & chloroform & 2.71 & \\
\hline
\end{tabular}




\begin{tabular}{|c|c|c|c|}
\hline \multirow[t]{2}{*}{ Toxic } & ethanol & 7.13 & \\
\hline & water & 25.01 & \\
\hline \multirow{4}{*}{$\begin{array}{l}\text { Gyroporus castaneus (Bull.: Fr.) Quélet } \\
\text { Chestnut bolete } \\
\text { Edible after removing the stalk (indigestible) and well } \\
\text { cooking }\end{array}$} & cyclohexane & 1.64 & \multirow[t]{4}{*}{24.07} \\
\hline & chloroform & 1.05 & \\
\hline & ethanol & 4.47 & \\
\hline & water & 16.91 & \\
\hline \multirow{4}{*}{$\begin{array}{l}\text { Neoboletus luridiformis (Rostk.) Gelardi, Simonini \& } \\
\text { Vizzini } \\
\text { syn. : Boletus erythropus Pers. } \\
\text { Dotted stem bolete } \\
\text { Good edible when cooked }\end{array}$} & cyclohexane & 1.19 & \multirow[t]{4}{*}{26.05} \\
\hline & chloroform & 1.30 & \\
\hline & ethanol & 8.13 & \\
\hline & water & 15.43 & \\
\hline \multirow{4}{*}{$\begin{array}{l}\text { Rubroboletus lupinus (Fr.) Costanzo et al. } \\
\text { syn. : Boletus lupinus Fr. } \\
\text { Wolf bolete } \\
\text { Toxic when consumed raw }\end{array}$} & cyclohexane & 3.46 & \multirow[t]{4}{*}{33.54} \\
\hline & chloroform & 1.80 & \\
\hline & ethanol & 12.30 & \\
\hline & water & 15.98 & \\
\hline \multicolumn{4}{|l|}{ Ascomycota } \\
\hline \multirow{4}{*}{$\begin{array}{l}\text { Gyromitra esculenta (Pers.) Fr. } \\
\text { Brain mushroom, False morel } \\
\text { Deadly (but consumed in Finland after specific cooking) }\end{array}$} & cyclohexane & 1.06 & \multirow[t]{4}{*}{29.80} \\
\hline & chloroform & 0.89 & \\
\hline & ethanol & 3.80 & \\
\hline & water & 24.05 & \\
\hline \multirow{4}{*}{$\begin{array}{l}\text { Helvella crispa Bull. } \\
\text { White saddle } \\
\text { Suspect* }\end{array}$} & cyclohexane & 2.10 & \multirow[t]{4}{*}{26.70} \\
\hline & chloroform & 1.41 & \\
\hline & ethanol & 2.97 & \\
\hline & water & 20.22 & \\
\hline
\end{tabular}

*Although some guidebooks list Helvella crispa as edible, this species is now regarded with suspicion by many authors (monomethyl hydrazine). ${ }^{24,50}$ 
TABLE 2: Antibacterial evaluation of the mushroom extracts by dilution method

\begin{tabular}{|c|c|c|c|}
\hline \multirow{3}{*}{$\begin{array}{l}\text { Mushroom } \\
\text { extract }\end{array}$} & \multicolumn{3}{|c|}{ MIC; MIB in $\mu \mathrm{g} / \mathrm{mL}$ (MBC/MIC) on Gram-positive strains } \\
\hline & \multicolumn{2}{|c|}{ S. aureus } & \multirow[t]{2}{*}{ B. subtilis } \\
\hline & MRSA & MSSA & \\
\hline \multicolumn{4}{|l|}{ C. aegerita } \\
\hline cyclohexane & N.A. & N.A. & N.A. \\
\hline chloroform & N.A. & N.A. & N.A. \\
\hline ethanol & N.A. & N.A. & N.A. \\
\hline water & N.A. & N.A. & N.A. \\
\hline \multicolumn{4}{|l|}{ C. traganus } \\
\hline cyclohexane & N.A. & N.A. & N.A. \\
\hline chloroform & N.A. & N.A. & N.A. \\
\hline ethanol & N.A. & N.A. & N.A. \\
\hline water & N.A. & N.A. & N.A. \\
\hline \multicolumn{4}{|l|}{ G. castaneus } \\
\hline cyclohexane & $125 ; 500(4)$ & $125 ;>500(>4)$ & N.A. \\
\hline chloroform & $125 ;>500(>4)$ & N.A. & N.A. \\
\hline ethanol & N.A. & N.A. & N.A. \\
\hline water & N.A. & N.A. & N.A. \\
\hline \multicolumn{4}{|c|}{ N. luridiformis } \\
\hline cyclohexane & $250 ;>500$ (n.d.) & $125 ;>500$ (n.d.) & N.A. \\
\hline chloroform & N.A. & $500 ;>500$ & N.A. \\
\hline ethanol & N.A. & N.A. & N.A. \\
\hline water & N.A. & N.A. & N.A. \\
\hline \multicolumn{4}{|l|}{ R. lupinus } \\
\hline cyclohexane & $125 ;>500(>4)$ & $250 ; 500(2)$ & 250; >500 (n.d.) \\
\hline
\end{tabular}




\begin{tabular}{|c|c|c|c|}
\hline chloroform & N.A. & N.A. & N.A. \\
\hline ethanol & N.A. & N.A. & N.A. \\
\hline water & N.A. & N.A. & N.A. \\
\hline \multicolumn{4}{|l|}{ G. esculenta } \\
\hline cyclohexane & $31 ; 125(4)$ & $31 ; 125(4)$ & $125 ;>500$ (n.d.) \\
\hline chloroform & $125 ;>500(>4)$ & $125 ; 125(1)$ & N.A. \\
\hline ethanol & N.A. & N.A. & N.A. \\
\hline water & N.A. & N.A. & N.A. \\
\hline \multicolumn{4}{|l|}{ H. crispa } \\
\hline cyclohexane & 500; >500 (n.d.) & 500; >500 (n.d.) & N.A. \\
\hline chloroform & $500 ;>500$ (n.d.) & $500 ;>500$ (n.d.) & N.A. \\
\hline ethanol & N.A. & N.A. & N.A. \\
\hline water & N.A. & N.A. & N.A. \\
\hline
\end{tabular}

As all extracts are inactive (MIC and MBC $>500 \mu \mathrm{g} / \mathrm{mL}$ ) against Gram-negative strains $(P$.

aeruginosa and E. coli) the results are not represented here. N.A.: non active, MIC > $500 \mu \mathrm{g} / \mathrm{mL}$ and MIB > $500 \mu \mathrm{g} / \mathrm{mL}$, n.d.: not determined 